\title{
FISCAL EQUALISATION: PRINCIPLES AND AN APPLICATION TO THE EUROPEAN UNION
}

\author{
BERND HAYO \\ MATTHIAS WREDE
}

CESIFO WORKING PAPER NO. 845

CATEgory 1: Public FinANCE

JANUARY 2003
An electronic version of the paper may be downloaded
- from the SSRN website: www.SSRN.com
- from the CESifo website: www.CESifo.de




\title{
FISCAL EQUALISATION: PRINCIPLES AND AN APPLICATION TO THE EUROPEAN UNION
}

\begin{abstract}
The paper derives a normative model for partial fiscal equalisation based on a number of axioms and allows for the existence of a specific fiscal need in the jurisdictions. The theoretical model is then empirically tested for the case of the European Union using data from 1986-97. It is found that most restrictions of the model appear to hold, in particular, relatively richer countries contribute more and those with greater fiscal needs, approximated by the importance of the agricultural sector, pay less. However, in the EU, an adjustment of net payments to changes in the actual importance of the spe-cific fiscal need for a country is lacking.
\end{abstract}

JEL Classification: H77, H87.

\author{
Bernd Hayo \\ Department of Economics \\ University of Essen \\ 45117 Essen \\ Germany \\ bhayo@vwl.uni-essen.de
}

\author{
Matthias Wrede \\ Department of Economics \\ and Business Administration \\ Aachen University \\ 52056 Aachen \\ Germany \\ mwr@fiwi.rwth-aachen.de
}

The paper was presented at the CESifo Area Conference on Public Sector Economics 2001 in Munich and at a research seminar in Berlin. Thanks to the participants, Matthias Brückner, Johann Brunner, Jeremy Edwards, Friedrich Heinemann, Eckhard Janeba, Roland Strausz, and Alfons Weichenrieder for helpful comments. Special thanks to an anonymous referee for many detailed suggestions. All remaining errors are our own. 


\section{Introduction}

Fiscal equalisation is an important aspect of the set-up of a multitude of forms of federal government. In setting up equalisation schemes between jurisdictions within one federation, both efficiency (insurance) and redistributive goals can be achieved. In practice, it is difficult to distinguish between those motives. A highly contested question centres on the type of fiscal equalisation that is being perceived as fair.

Like many studies involving value judgements, this paper sets out to derive an idealised fiscal equalisation scheme based on an explicit axiomatic foundation. Using explicit criteria that should be fulfilled by the final equalisation scheme is a helpful way to guide the debate. One can disagree with the axioms, but if one accepts those, one must also accept the conclusion, which we define as fair. Consequently, we attempt to apply only those axioms that have the potential for gathering widespread support.

A unique feature of our model is the incorporation of specific expenditures to cope with certain needs in the member countries of the fiscal union, which allows for a more realistic modelling of the redistribution of funds than usually employed in the theoretical literature. Fiscal equalisation is often directed at particular disadvantages of fiscal jurisdictions, which are beyond their immediate control. By directly including the idea of 'fiscal need', we explicitly incorporate this feature of the real world. This also makes the analysis more applicable to empirical data.

The theoretical results show that key variables for the determination of net contributions are average gross income of the union and gross income of the respective member states, as well as average gross specific expenditures and local specific expenditures by the union.

As a next step, an explicit and empirically estimable functional form is directly derived from the theoretical model. In the empirical section of the paper, this idealised 
model is applied to the European Union (EU) to test whether the theoretical considerations are reflected in this example of a fiscal equalisation scheme. Since member-state contribution to the EU is a hotly debated issue, being able to compare the actual distribution of funds with an ideal scheme might facilitate a rational and educated discussion.

Sometimes redistribution within the EU is portrayed as lacking all foundations for a fair system. Instead, it is regarded as the unsatisfactory result of a power struggle between governments. We do not disagree with the statement that political power plays a role in determining many aspects of the equalisation scheme. However, we believe that simply dismissing the outcome of such negotiations as unfair is throwing the baby out with the bath water. As will become apparent in our empirical analysis, the EU equalisation scheme does, to a certain extent, conform to a specific version of a fair redistribution allowing for specific fiscal needs. Note, however, that we do not take the effect of a redistribution scheme on efficiency into account. When we speak about an ideal redistribution system, we refer to the outcome of our axiomatic analysis, which does not include the aspect that different redistribution schemes may generate differing deadweight losses.

In the empirical part of the paper, we combine observations from EU member countries over the time period 1986 to 1997 to form a panel data set of per-capita variables. First, it is tested whether the coefficients on EU average variables are equal in absolute value to the coefficients on the member-country variables. Second, imposing this restriction and using deviations from EU average values as regressors, it is then analysed whether the empirical results correspond with the idealised theoretical model.

The final section contains a summary of the results and a brief discussion of the implications for economic policy. 


\section{Axiomatic approach towards fiscal equalisation}

Fiscal equalisation ${ }^{1}$ takes place among $n$ jurisdictions, where $n \geq 3$. Jurisdiction $i$, $\mathrm{i}=1, \ldots, \mathrm{n}$, is characterised by (non-negative) gross income $\mathrm{Y}_{\mathrm{i}}$, by certain (nonnegative) expenditure $\mathrm{E}_{\mathrm{i}}$ (= specific fiscal need), and by the (non-negative) population $Z_{i}$. In order to simplify notation, total income $Y=\sum_{j=1}^{n} Y_{j}$, total expenditure $E=\sum_{j=1}^{n} E_{j}$ and the share in population $z_{i}=Z_{i} / \sum_{j=1}^{n} Z_{j}, i=1, \ldots, n$, are defined. Net income $F_{i}$ in jurisdiction $i, i=1, \ldots, n$, depends on gross income, expenditure and population in all $\mathrm{n}$ jurisdictions

$$
\mathrm{F}_{\mathrm{i}}=\mathrm{F}_{\mathrm{i}}\left(\mathrm{Y}_{1}, \ldots, \mathrm{Y}_{\mathrm{n}}, \mathrm{E}_{1}, \ldots, \mathrm{E}_{\mathrm{n}}, \mathrm{Z}_{1}, \ldots, \mathrm{Z}_{\mathrm{n}}\right) \text {, where } \mathrm{F}_{\mathrm{i}}: \mathfrak{R}_{+}^{3 \mathrm{n}} \rightarrow \mathfrak{R} \text { and } \sum_{\mathrm{j}=1}^{\mathrm{n}} \mathrm{Z}_{\mathrm{j}}>0
$$

It is natural to base fiscal equalisation on gross income and population. Due to various reasons, however, certain expenditures could be included separately in the fiscal equalisation scheme. For instance, because of external effects or an uneven distribution across jurisdictions. In the context of an axiomatic approach, a specific fiscal need should receive special consideration if this reflects the intention of the entire federation. How this consensus has been derived does not concern us here.

An equalisation method is considered which, apart from other properties, isolates each jurisdiction from certain changes in other jurisdictions.

1 The axiomatic approach towards fiscal equalization is closely related to Buhl and Pfingsten (1986, 1990, 1991). However, there exists a large strand of literature dealing with a fair distribution of funds. See, for example, Moulin (1987) and Young (1988). 
Definition 1: An isolating partial fiscal equalisation method satisfies $^{2}$

$$
\begin{aligned}
& F_{i}\left(Y_{1}, \ldots, Y_{n}, E_{1}, \ldots, E_{n}, Z_{1}, \ldots, Z_{n}\right)=0 \text { if } Y_{i}=E_{i}=Z_{i}=0, \\
& \sum_{i=1}^{n} F_{i}\left(Y_{1}, \ldots, Y_{n}, E_{1}, \ldots, E_{n}, Z_{1}, \ldots, Z_{n}\right)=Y-E \\
& -E \leq F_{i}\left(Y_{1}, \ldots, Y_{n}, E_{1}, \ldots, E_{n}, Z_{1}, \ldots, Z_{n}\right) \leq Y, \text { for all } i, i=1, \ldots, n, \\
& F_{i}\left(Y_{1}, \ldots, Y_{i}, \ldots, Y_{j}, \ldots, Y_{n}, E_{1}, \ldots, E_{i}, \ldots, E_{j}, \ldots, E_{n}, Z_{1}, \ldots, Z_{i}, \ldots, Z_{j}, \ldots, Z_{n}\right) \\
& =F_{j}\left(Y_{1}, \ldots, Y_{j}, \ldots, Y_{i}, \ldots, Y_{n}, E_{1}, \ldots, E_{j}, \ldots, E_{i}, \ldots, E_{n}, Z_{1}, \ldots, Z_{j}, \ldots, Z_{i}, \ldots, Z_{n}\right),
\end{aligned}
$$$$
\text { for all } i, j, i=1, \ldots, n, j=1, \ldots, n, i \neq j \text {, }
$$$$
F_{i}\left(Y_{1}, \ldots, Y_{n}, E_{1}, \ldots, E_{n}, Z_{1}, \ldots, Z_{n}\right)=F_{i}\left(Y_{1}, \ldots, Y_{n}, E_{1}, \ldots, E_{n}, \lambda Z_{1}, \ldots, \lambda Z_{n}\right),
$$

for all $\lambda>0$,

$$
F_{i}\left(\widetilde{Y}_{1}, \ldots, \widetilde{Y}_{n}, \widetilde{E}_{1}, \ldots, \widetilde{E}_{n}, \widetilde{Z}_{1}, \ldots, \widetilde{Z}_{n}\right)=F_{i}\left(Y_{1}, \ldots, Y_{n}, E_{1}, \ldots, E_{n}, Z_{1}, \ldots, Z_{n}\right)
$$

where $\tilde{Y}_{j}=Y_{j}+Y_{k}, \tilde{Y}_{k}=0, \tilde{Y}_{m}=Y_{m}$,

$\widetilde{\mathrm{E}}_{\mathrm{j}}=\mathrm{E}_{\mathrm{j}}+\mathrm{E}_{\mathrm{k}}, \widetilde{\mathrm{E}}_{\mathrm{k}}=0, \widetilde{\mathrm{E}}_{\mathrm{m}}=\mathrm{E}_{\mathrm{m}}, \widetilde{\mathrm{Z}}_{\mathrm{j}}=\mathrm{Z}_{\mathrm{j}}+\mathrm{Z}_{\mathrm{k}}, \widetilde{\mathrm{Z}}_{\mathrm{k}}=0, \widetilde{\mathrm{Z}}_{\mathrm{m}}=\mathrm{Z}_{\mathrm{m}}$,

for all $m, m=1, \ldots, n, m \neq j, m \neq k$,

for all $i, j, k, i=1, \ldots, n, j=1, \ldots, n, k=1, \ldots, n, i \neq j, i \neq k, j \neq k$.

The first four properties define a pure sharing funds method. The empty jurisdiction property (A1) says that net income in a jurisdiction without people, gross income, and expenditure ought to be zero. In other words, money should not be given to empty jurisdictions. Property (A2) postulates a full distribution of funds. The described fiscal equalisation method is a pure sharing funds method. Thus, total income net of expendi-

\footnotetext{
2 All properties with the exception of the first property should be fulfilled for all feasible values of income, fiscal need and population. Only property (A1) considers special parameter values for the jurisdiction under consideration.
} 
ture has to be the same before and after partial equalisation. Property (A3) introduces a lower and an upper bound. No jurisdiction is burdened with more than total expenditure and the net income after equalisation should not exceed total income of the entire federation. Property (A4) states anonymity. The assignment of numbers to jurisdictions is irrelevant. $^{3}$

Properties (A5) and (A6) impose restrictions on funds sharing methods. Property (A5) assumes homogeneity of degree zero with respect to population. Proportional population changes in all jurisdictions do not alter the net income of any jurisdiction. Property (A6) states independence of mergers outside the jurisdiction. This property requires that a merger between two jurisdictions does not affect any other jurisdiction. On the one hand, this axiom is derived from the subsidiarity principle. As long as there are no external effects, a merger should be just an affair of the acting jurisdictions. On the other hand, property (A6) rules out strategic mergers between jurisdictions to the disadvantage of outsiders. Finally, property (A6) also ensures that rich jurisdictions are not interested in mergers of poor jurisdictions. ${ }^{4}$

Monotonicity of the fiscal equalisation method is required to preserve incentives and to maintain the order of jurisdictions:

Definition 2: A monotonic isolating partial fiscal equalisation method fulfils for all $i, j, i=1, \ldots, n, j=1, \ldots, n$,

$$
F_{i}\left(Y_{1}, \ldots, Y_{n}, E_{1}, \ldots, E_{n}, Z_{1}, \ldots, Z_{n}\right) \text { is non-increasing with respect to } E_{j} \text {, }
$$

risdiction under consideration.

3 An approach that violates anonymity is discussed by Aczél and Pfingsten (1993). 
for all $i, j, i=1, \ldots, n, j=1, \ldots, n$,

(A9) $F_{i}\left(Y_{1}, \ldots, Y_{n}, E_{1}, \ldots, E_{n}, Z_{1}, \ldots, Z_{n}\right)$ is non-decreasing with respect to $Z_{i}$,

for all $\mathrm{i}, \mathrm{i}=1, \ldots, \mathrm{n}$. \#

Property (A7) is monotonicity with respect to gross income. Property (A8) is monotonicity with respect to expenditure. Property (A9) is monotonicity with respect to its own population. Properties (A7) and (A8) ensure that net income in a certain jurisdiction is not negatively affected through the specific equalisation method employed when incomes in other jurisdictions increase and is not positively affected when fiscal needs in other jurisdictions increase. Axiom (A9) reflects a basic condition for distributional fairness. An increase in population in one particular jurisdiction should not decrease the available funds for that jurisdiction.

Using these definitions, the following main result can be derived (and is proven in the appendix).

Theorem 1: If net income functions $\mathrm{F}_{\mathrm{i}}: \mathfrak{R}_{+}^{3 \mathrm{n}} \rightarrow \mathfrak{R}, \mathrm{i}=1, \ldots, \mathrm{n}$, constitute an isolating partial fiscal equalisation method, i.e., if they satisfy properties (A1) till (A6), there exist functions

$$
\begin{aligned}
& \mathrm{f}_{\mathrm{Y}}=\mathrm{f}_{\mathrm{Y}}(\mathrm{Y}, \mathrm{E}) \text {, where } \mathrm{f}_{\mathrm{Y}}: \mathfrak{R}_{+}^{2} \rightarrow \mathfrak{R}, \\
& \mathrm{f}_{\mathrm{E}}=\mathrm{f}_{\mathrm{E}}(\mathrm{Y}, \mathrm{E}) \text {, where } \mathrm{f}_{\mathrm{E}}: \mathfrak{R}_{+}^{2} \rightarrow \mathfrak{R},
\end{aligned}
$$

so that, for all $i, i=1, \ldots, n$,

$$
\begin{aligned}
& F_{i}\left(Y_{1}, \ldots, Y_{n}, E_{1}, \ldots, E_{n}, Z_{1}, \ldots, Z_{n}\right) \\
& =f_{Y}(Y, E) Y_{i}-f_{E}(Y, E) E_{i}+\left[\left(1-f_{Y}(Y, E)\right) Y-\left(1-f_{E}(Y, E)\right) E\right] z_{i}
\end{aligned}
$$

4 In Germany mergers of states matter. For example, federal grants and fiscal equalisation grants from 
The theorem states that an isolating partial fiscal equalisation method requires net income in a particular jurisdiction to depend on its own gross income, on total income, on its own expenditure, on total expenditure and on the population share. Moreover, the net income function is a linear function of the population share of the jurisdiction, and the coefficient in square brackets is determined by total income and total expenditure. Very small jurisdictions will take the coefficient as given since their own income and expenditure have only minor influence on the functions $f_{Y}$ and $f_{E}$.

As shown in the appendix, monotonicity properties and range requirements for the functions $f_{Y}$ and $f_{E}$ have to be imposed for monotonic isolating partial fiscal equalisation methods.

Theorem 2: A monotonic isolating partial fiscal equalisation method requires (a) that $f_{Y}(Y, E)\left[f_{E}(Y, E)\right]$ is non-decreasing [non-increasing] with respect to $Y$ and nonincreasing [non-decreasing] with respect to $E$ and (b) that $0 \leq \mathrm{f}_{\mathrm{E}}(\mathrm{Y}, \mathrm{E}) \leq 1$ and $0 \leq \mathrm{f}_{\mathrm{Y}}(\mathrm{Y}, \mathrm{E}) \leq 1$ have to be fulfilled.

A natural monotonic isolating partial fiscal equalisation method is described by the next theorem:

Theorem 3: Net income functions $\mathrm{F}_{\mathrm{i}}: \mathfrak{R}_{+}^{3 \mathrm{n}} \rightarrow \mathfrak{R}, \mathrm{i}=1, \ldots, \mathrm{n}$, constitute a monotonic isolating partial fiscal equalisation method, i.e., they satisfy properties (A1) till (A9) for $Y>E$, if for all $i, i=1, \ldots, n$,

$$
F_{i}\left(Y_{1}, \ldots, Y_{n}, E_{1}, \ldots, E_{n}, Z_{1}, \ldots, Z_{n}\right)=c Y_{i}-d E_{i}+[(1-c) Y-(1-d) E] z_{i}
$$

where the real numbers $\mathrm{c}$ and $\mathrm{d}$ fulfil $0 \leq \mathrm{c} \leq \mathrm{d} \leq 1$.

Proof: Equation (2) satisfies (A1), (A2), (A4), (A5) and (A6). (A7) is guaranteed by $0 \leq \mathrm{c} \leq 1.0 \leq \mathrm{d} \leq 1$ ensures (A8). (A9) is ensured by $\mathrm{c} \leq \mathrm{d}$ since $\mathrm{Y}>\mathrm{E}$. Due to 
$0 \leq \mathrm{c} \leq 1, \mathrm{cY} \mathrm{i}_{\mathrm{i}}+(1-\mathrm{c}) \mathrm{Y} \leq \mathrm{Y}$ and thus $\mathrm{cY} \mathrm{Y}_{\mathrm{i}}+(1-\mathrm{c}) \mathrm{Yz}_{\mathrm{i}} \leq \mathrm{Y}$, for all i. Hence, because of $0 \leq \mathrm{d} \leq 1$ the upper bound determined by (A3) is not violated. By a similar argument, it can be shown that the lower bound of (A3) is fulfilled.

QED

However, not only (2) is a monotonic isolating partial fiscal equalisation method. For instance, the following scheme also fulfils properties (A1) till (A9) (see the appendix for the monotonicity properties), provided that $\mathrm{Y}>\mathrm{E}$,

$$
\mathrm{F}_{\mathrm{i}}=(\mathrm{Y}-\mathrm{E}) \mathrm{Z}_{\mathrm{i}}+\frac{\arctan (\mathrm{Y})}{\pi}\left(\mathrm{Y}_{\mathrm{i}}-\mathrm{Yz}_{\mathrm{i}}\right)-\frac{\arctan (\mathrm{E})}{\pi}\left(\mathrm{E}_{\mathrm{i}}-\mathrm{Ez}_{\mathrm{i}}\right)
$$

Since $0 \leq \arctan (x) / \pi<1 / 2$ for $x \geq 0$, by a similar argument as in the proof of theorem 3, it can be shown that (3) lies in the interval determined by (A3).

With respect to gross income and population, the partial equalisation method (2) has been suggested by Buhl and Pfingsten (1991). ${ }^{5}$ Neglecting expenditure (and also federal funds which have been considered by Buhl and Pfingsten), a comparison of the two approaches is worthwhile. Properties total distribution (A2), anonymity (A4), homogeneity of degree zero with respect to population (A5), independence of mergers outside the jurisdiction (A6), and monotonicity with respect to gross income (A7) and population (A9) are common axioms. However, because of the lower and upper bound introduced by axiom (A3) this paper does not require monotonicity for theorem 1. Moreover, the empty-jurisdiction property (A1) is not explicitly stated in Buhl and Pfingsten (1991). They, however, require additionally what they call independence of population distribution and independence of the length of the equalisation method. The former property requires that migration between jurisdictions should not affect other

5 See also Buhl and Pfingsten (1986, 1990). 
jurisdictions. The latter property is formally (adapting our notation to the case without expenditure)

$$
\begin{aligned}
& F_{i}\left(\hat{Y}_{1}, \ldots, \hat{Y}_{n}, Z_{1}, \ldots, Z_{n}\right)+F_{i}\left(Y_{1}, \ldots, Y_{n}, Z_{1}, \ldots, Z_{n}\right) \\
& =F_{i}\left(Y_{1}+\hat{Y}_{1}, \ldots, Y_{n}+\hat{Y}_{n}, Z_{1}, \ldots, Z_{n}\right) .
\end{aligned}
$$

Independence of the length of the equalisation method is a strong assumption. It leads to a functional form that includes sums of individual jurisdiction values for income and expenditure. The coefficients in this specification are independent of aggregate values. Due to this property, in the scenario described by Buhl and Pfingsten the equalisation method (2) is not only sufficient - as stated by the previous theorem - but also necessary.

\section{Partial fiscal equalisation in the European Union}

The EU is an interesting and topical case for assessing the practical importance of an idealised fiscal redistribution framework. Although no explicit fiscal equalisation scheme exists in the European Union, only a small fraction of EU expenditures (roughly $8 \%)^{6}$ is allocated to common purposes. This implies that the major part of EU expenditures directly flows back into member countries. These direct flows to and from the EU can be interpreted as reflecting a fiscal redistribution policy across member countries. ${ }^{7}$

An important question in the empirical analysis is the choice of an appropriate variable to capture a specific fiscal need. The EU is a very good testing ground for this reason, as it is relatively easy to determine the main fiscal need. In our view, this is the agricul-

\footnotetext{
Wissenschaftlicher Beirat beim Bundesministerium für Wirtschaft und Technologie (1999), p. 3.

7 Some caveats of such an interpretation are listed in Bundesbank (1999), p. 65.
} 
tural sector, as expenditures on agriculture are still the most important single item in the EU budget (51\% in 1996).

The data cover the time period $1986-97$ and up to 14 countries. $^{8}$ All series are in ECU and in per-capita terms. ${ }^{9}$ Net contributions to the EU budget are derived by subtracting direct EU payments to member countries from 'own resources' of EU by member country. ${ }^{10}$ The importance of the agricultural sector as a special fiscal need is proxied by the ratio of gross value added of the agricultural sector (including forestry and fishing) to overall gross value added in market prices (AGR). Gross domestic product (GDP) is used as a proxy for gross income. ${ }^{11}$ Variable names with a subscript $\mathrm{i}$ denote values for EU member countries and names without a subscript are average EU values.

This section empirically analyses whether the implicit fiscal equalisation scheme in the EU is in line with the ideal scheme derived in the theoretical section. ${ }^{12}$ For that purpose, the monotonic isolating partial fiscal equalisation method (2) with constant coefficients will be used to derive an explicit functional form.

The net income function (2) can be written as

8 Luxembourg is excluded from the analysis as relevant data are missing. Some data on agricultural shares are missing for Greece and Portugal, reducing the number of observations from 141 to 135.

9 Data are taken from various issues of Statistisches Jahrbuch für das Ausland, which is compiled by the Statistisches Bundesamt, Wiesbaden, Germany.

10 Although the EU cannot levy its own taxes to generate revenues, it nevertheless has its 'own resources'. These consist of custom duties (17\% in 1996), agricultural levies (2\%), value-added tax share (48\%), and GDP share (33\%).

11 GNP could be considered a more appropriate income aggregate in this context. However, there are difficulties in getting consistent data for the sample period for all countries. In any case, the correlation between GNP and GDP for the countries at hand is always at least 0.99 which makes them equivalent in the empirical analysis.

12 An earlier analysis by Bowles and Jones (1992) looks separately at determinants for payments to the EU budget and EU own resources without the guidance of a specific economic model. 


$$
F_{i}=Y_{i}-E_{i}-T_{i},
$$

where $T_{i}=(1-c) Y_{i}-(1-d) E_{i}+f z_{i}$

where $\mathrm{f}=(1-\mathrm{d}) \mathrm{E}-(1-\mathrm{c}) \mathrm{Y}$.

$T_{i}$ is the net contribution of jurisdiction $i$ to the equalisation funds. Dividing $T_{i}$ by the population leads to the per-capita contribution

(6)

$$
\mathrm{t}_{\mathrm{i}}=(1-\mathrm{c}) \mathrm{y}_{\mathrm{i}}-(1-\mathrm{d}) \mathrm{e}_{\mathrm{i}}+\mathrm{g}
$$

where $g=(1-d) e-(1-c) y$,

and per-capita variables are denoted by lowercase letters:

$$
\mathrm{t}_{\mathrm{i}}=\mathrm{T}_{\mathrm{i}} / \mathrm{Z}_{\mathrm{i}}, \mathrm{y}_{\mathrm{i}}=\mathrm{Y}_{\mathrm{i}} / \mathrm{Z}_{\mathrm{i}}, \mathrm{e}_{\mathrm{i}}=\mathrm{E}_{\mathrm{i}} / \mathrm{Z}_{\mathrm{i}}, \mathrm{y}=\mathrm{Y} / \sum_{\mathrm{j}=1}^{\mathrm{n}} \mathrm{Z}_{\mathrm{j}}, \mathrm{e}=\mathrm{E} / \sum_{\mathrm{j}=1}^{\mathrm{n}} \mathrm{Z}_{\mathrm{j}} \cdot
$$

In words, net contributions to the EU depend on gross incomes of member states, EU income, member countries' specific fiscal expenditures and EU specific expenditures (all variables in per-capita). Based on (6), the following empirical model is estimated:

(7) Net contributions it $_{\text {it }}=\beta_{1} \mathrm{GDP}_{\text {it }}+\beta_{2} \mathrm{GDP}_{\mathrm{t}}+\beta_{3} \mathrm{AGR}_{\text {it }}+\beta_{4} \mathrm{AGR}_{\mathrm{t}}+\varepsilon_{\text {it }}$, with $\mathrm{E} \varepsilon_{\mathrm{i}, \mathrm{t}}=0$ and $\operatorname{Var} \varepsilon_{\mathrm{i}, \mathrm{t}}=\sigma^{2}$, i country index, $\mathrm{t}$ time index.

Table 1 gives the results of estimating this model using ordinary least squares (OLS). 
Tab. 1: Testing restrictions on equation (6) (Observations: 135)

\begin{tabular}{lrr|rr}
\hline Variables & Coefficients & SEs & Robust SEs & Adjusted SEs \\
\hline GDP $_{\text {it }}$ & $0.007^{*}$ & $(0.003)$ & $(0.002)$ & $(0.003)$ \\
GDP $_{\mathrm{t}}$ & $-0.008^{*}$ & $(0.004)$ & $(0.003)$ & $(0.005)$ \\
AGR $_{\text {it }}$ & $-37.4^{* *}$ & $(4.04)$ & $(5.2)$ & $(13.8)$ \\
AGR $_{\mathrm{t}}$ & $29.4^{* *}$ & $(8.12)$ & $(9.5)$ & $(15.0)$ \\
F-test $^{2}$ & $\mathrm{~F}(4,131)=52.22^{* *}$ & & \\
$\mathrm{R}^{2}$ & 0.62 & $\mathrm{~F}(1,131)=0.53$ & $\mathrm{~F}(1,131)=0.36$ & $\mathrm{Chi}^{2}(1)=0.19$ \\
Test: $\beta_{1}=-\beta_{2}$ & $\mathrm{~F}(1,131)=1.27$ & $\mathrm{~F}(1,131)=0.99$ & $\mathrm{Chi}^{2}(1)=0.81$ \\
Test: $\beta_{3}=-\beta_{4}$ & & \\
\hline
\end{tabular}

Notes: ${ }^{*}(*)$ indicates significance at a 5\% (1\%) level.

The coefficients reported in column 2 are all statistically significant using the normal standard errors (SEs) in column 3, and they display theoretically consistent signs. In the theoretical model, coefficients (1-d) and (1-c) have to be the same for income and expenditure on the individual and aggregate level, respectively. ${ }^{13}$ In the empirical model, this implies testing the restrictions $\beta_{1}=-\beta_{2}$ and $\beta_{3}=-\beta_{4}$. The last two lines of the table report test statistics for these restrictions, and they cannot be rejected based on normal standard errors .

However, there are potential difficulties related to the calculation of standard errors. A typical problem in a panel framework is a violation of the homoscedasticity assumption $\left(\operatorname{Var}_{\mathrm{i}, \mathrm{t}}=\sigma^{2}\right)$, i.e. the variance is not constant over all values of the independent variables. Column 4 presents robust standard errors based on the procedure

13 Another restriction in the theoretical model is that $\mathrm{c} \leq \mathrm{d}$. This will not hold in the empirical model, though, as in the theoretical model the coefficient refers to specific expenditures, while in the empirical model the share of agriculture in gross value added is used to proxy the specific needs. 
pendent variables. Column 4 presents robust standard errors based on the procedure proposed by White (1980). The relative similarity of robust standard errors with normal standard errors shows that heteroscedasticity is not a major problem here.

There is another issue related to deriving correct standard errors for variables sampled at different aggregation levels (EU aggregate vs. member country). The normal standard errors might be downward biased (see Moulton 1990). Appropriately adjusted standard errors are shown in the last column. Indeed, standard errors have increased substantially but the test for equality does still not reject. Thus in the following analysis, these restrictions are imposed on the model to increase the efficiency of the estimates.

In other words, deviations from the EU average are used as regressors in the final analysis. The estimated restricted model is:

$$
\begin{aligned}
& \text { Net contributions } s_{i t}=\beta_{1}\left(G P_{i t}-G D P_{t}\right)+\beta_{3}\left(A_{G R} i t-A_{i t}\right)+\varepsilon_{i t}, \\
& \text { with } \varepsilon_{i t}=u_{i}+v_{i t} \text {, } \\
& u_{i} \text { unobservable individual specific effect, } v_{i t} \text { remaining disturbance. }
\end{aligned}
$$

The robustness of the estimation results is investigated by making different assumptions about the error term of model (8). The between-effects model (BE) uses only the cross-sectional variation by averaging over the time dimension for each country. OLS $_{1}$ is model (7) with the restrictions on the parameters imposed, OLS 2 includes a constant, and $\mathrm{OLS}_{3}$ adds time dummies. Finally, FE is a fixed effects estimator (withineffects estimator), which takes into account country dummies in addition to time dummies. $^{14}$

Table 2 shows that the coefficient on $\mathrm{GDP}_{\mathrm{it}}-\mathrm{GDP}_{\mathrm{t}}$ is estimated relatively robust across different specifications. In accordance with the theoretical model, we get positive

\footnotetext{
${ }^{14}$ See Baltagi (1995) for a discussion of different specifications for panel data models.
} 
estimates, most of which are significant. The results are also quite consistent across differing empirical specifications in the case of $A_{G R} \mathrm{it}^{-}-\mathrm{AGR}_{\mathrm{t}}$. In all regressions except for FE, the effect is negative, as we would expect from the theoretical model, and highly significant. Even after controlling for the variations in GDP, fiscal need is a powerful determinant of fiscal equalisation flows.

Tab. 2: Explaining per-capita net contributions to EU budget

\begin{tabular}{|c|c|c|c|c|c|}
\hline Variables & $\mathrm{BE}$ & $\mathrm{OLS}_{1}$ & $\mathrm{OLS}_{2}$ & $\mathrm{OLS}_{3}$ & $\mathrm{FE}$ \\
\hline \multirow{2}{*}{$\mathrm{GDP}_{\mathrm{it}}-\mathrm{GDP}_{\mathrm{t}}$} & 0.005 & 0.006 & $0.007 * *$ & $0.006^{*}$ & $0.01 * *$ \\
\hline & $(0.008)$ & $(0.003)$ & $(0.002)$ & $(0.003)$ & $(0.005)$ \\
\hline \multirow[t]{2}{*}{$\mathrm{AGR}_{\mathrm{it}}-\mathrm{AGR}_{\mathrm{t}}$} & $-40.2 * *$ & $-39.1 * *$ & $-37.2 * *$ & $-38.5 * *$ & $71.4^{* *}$ \\
\hline & (11.1) & (4.4) & (4.1) & (4.1) & $(9.5)$ \\
\hline Constant & Yes & No & Yes & Yes & Yes \\
\hline Time effects & n.a. & No & No & Yes & Yes \\
\hline Country effects & n.a. & No & No & No & Yes \\
\hline \multirow[t]{2}{*}{ F-test } & $\mathrm{F}(2,11)$ & $\mathrm{F}(2,133)$ & $\mathrm{F}(2,132)$ & $\mathrm{F}(13,121)=$ & $\mathrm{F}(13,108)=$ \\
\hline & $=14.7 * *$ & $=74.8^{* *}$ & $=87.4^{* *}$ & $13.8^{* *}$ & $6.9 * *$ \\
\hline $\mathrm{R}^{2}$ & 0.73 & 0.53 & 0.57 & 0.60 & 0.46 \\
\hline
\end{tabular}

However, there is a clear exception from this conclusion: the FE model. ${ }^{15}$ After including country fixed-effects, the sign of the coefficient changes. It is worthwhile to

\footnotetext{
${ }^{15}$ Employing a Hausman-test (Hausman 1978) leads to a rejection of a random-effects model in favour of the FE model $\left(\mathrm{Chi}^{2}(2)=84 * *\right)$.
} 
investigate the source for this sign reversal in somewhat more detail to better understand what is going on.

One can show that the parameter estimates for the country dummies are highly correlated with $\mathrm{AGR}_{\mathrm{it}}-\mathrm{AGR}_{\mathrm{t}}$ (correlation coefficient is 0.90). This indicates that the fiscal equalisation scheme of the EU is geared towards compensating countries for a specific fiscal need. This explains the theoretically consistent negative coefficient obtained in the other model specifications. In the FE model the redistribution aspect is captured by the country dummies, which are time invariant. After accounting for the static redistribution captured by the dummies, the $A G R_{i t}-A_{G R}$ variable picks up reverse redistribution based on the variation across time.

We interpret this finding as follows: the political process behind the compensation of specific fiscal needs is not flexible enough to allow for a continuous adjustment in the equalisation scheme. Due to the nature of the bargaining game going on between EU member countries, it is always easier to maintain the status quo than to introduce changes (see Molle 1997).

Interpreting the empirical results within the context of our theoretical model of fiscal equalisation allows for a better understanding of this aspect of EU redistribution. The EU conforms to an ideal scheme of fiscal equalisation to the extent that GDP differences matter, and so do specific fiscal needs in the form of a large agricultural burden. However, redistribution is not continuously adjusted to account for changes in actual fiscal needs due to frictions arising from negotiations between sovereign governments with veto power trying to protect their interests. In our view, this problem lies at the heart of many complaints about the equity of the current system. 


\section{Summary and conclusion}

Using an axiomatic approach, this paper derives a partial fiscal equalisation scheme that not only takes income into consideration but also allows for specific fiscal needs. The idealised theoretical model demonstrates that net contributions ought to depend on average union gross income, member states gross income, average union specific fiscal need, and members states specific fiscal needs. The derived functional form of the partial fiscal equalisation mechanism is similar to the scheme developed by Buhl and Pfingsten (1986, 1990, 1991). A major difference is, however, that the independence-ofmergers-outside-the-jurisdiction axiom used in the present paper does not directly set up a Cauchy-type functional equation for income and fiscal need in all jurisdictions.

As a special case of our more general partial fiscal equalisation scheme, we derive a simple mechanism that relates net contributions to deviations of member state values for gross income and specific fiscal need from their respective union average that can be considered as an extension of the Buhl-Pfingsten scheme.

We apply this idealised simple mechanism of partial fiscal equalisation to the European Union (EU), employing data from 1986 to 1997 for up to 14 countries. This is a particularly useful testing ground. One can compute net contributions from member states to the EU, and it is easy to identify the main fiscal need by analysing the EU budget. This investigation reveals that the agricultural sector plays the most prominent role in the EU budget. Consequently, we use the importance of the agricultural sector in the economy as an indicator of the fiscal need of a country.

In the first step of a regression approach with net contributions to the EU budget as a dependent variable, it was found that the coefficients on aggregate EU GDP (agricultural share) and member countries' GDP (agricultural share) are of equal absolute 
size. This restriction is in accordance with our theoretical priors and is then imposed on the empirical model in the second part of the analysis.

The estimate of the effect of the deviation of individual member states' GDP from EU average on net contributions is positive. Thus, relatively richer countries pay more to the EU than poorer countries, as demanded in the idealised theoretical model. For the specific need proxy, the deviation of the agricultural gross value added from EU average, we find a negative parameter in most specifications: the larger the fiscal need, the lower the net contributions are. The sign gets reversed, however, in the case of a model including country dummies. Our interpretation of this finding is that although there is redistribution in line with the idealised theoretical model, the EU fiscal equalisation scheme does not continuously update to changes of actual fiscal needs.

To conclude, the EU equalisation scheme does to a certain extent conform to an idealised fiscal equalisation scheme based on a number of reasonable axioms. Hence general complaints about the system being unfair are not warranted. Instead, our analysis allows a more careful identification of the deficiency. It is the lack of adjustment to a change in the relative fiscal need that prevents the system from complying with the idealised equalisation scheme at all points in time.

In our opinion, this has a lot to do with the inability of the political process to reverse the status of countries from net recipient to net contributor. Perhaps it would be a useful idea to take actual fiscal equalisation away from the political bargaining agenda and hand it over to a more automatic mechanism or the EU Commission. Unfortunately, strong national interests guided by thinking in terms of keeping the status quo are likely going to torpedo such a suggestion.

With EU enlargement approaching, distributional issues are going to become even more important. Thus, institutional reforms appear to be necessary before new 
member states enter the political bargaining process. Otherwise, the EU might not only run into problems of limited finances but also of violating distributional ideals. The lack of fairness with regard to burden sharing might undermine the willingness of countries to contribute to the EU budget and exacerbate the financial problems after enlargement. One can also envision a change of policy preferences regarding the specification of fiscal need at the EU level. This would require, however, an unanimous agreement by national policy makers.

It should be emphasised that we do not argue EU expenditures are necessarily used efficiently. As has been pointed out many times before, especially the Common Agricultural Policy (CAP) is characterised by a number of shortcomings when evaluated using an efficiency criterion. In fact, most of the studies analysing the European budget have centred on the aspect of efficiency. However, we think that one should also take distributional aspects into account. Consequently, we propose that a desirable CAP reform ought to improve efficiency while maintaining the general distributional aspects of the current system, conditional on a more regular updating of net transfers according to changes in fiscal need. 


\section{Appendix}

\section{Proof of theorem 1}

Theorem 1 will be proved step by step. From (A5) follows

$$
F_{i}\left(Y_{1}, \ldots, Y_{n}, E_{1}, \ldots, E_{n}, Z_{1}, \ldots, Z_{n}\right)=F_{i}\left(Y_{1}, \ldots, Y_{n}, E_{1}, \ldots, E_{n}, z_{1}, \ldots, z_{n}\right)
$$

Using (A6) repeatedly,

$$
\begin{aligned}
& F_{1}\left(Y_{1}, \ldots, Y_{n}, E_{1}, \ldots, E_{n}, Z_{1}, \ldots, Z_{n}\right) \\
= & F_{1}\left(Y_{1}, 0, \ldots, 0, Y-Y_{1}, E_{1}, 0, \ldots, 0, E-E_{1}, z_{1}, 0, \ldots, 0,1-z_{1}\right) .
\end{aligned}
$$

can be derived. Generalising this result and taking the anonymity axiom (A4) into account, one derives the following Lemma:

Lemma 1: Net income functions $\mathrm{F}_{\mathrm{i}}: \mathfrak{R}_{+}^{3 \mathrm{n}} \rightarrow \mathfrak{R}, \mathrm{i}=1, \ldots, \mathrm{n}$ satisfy properties (A4), (A5) and (A6), only if there exists a function $\widetilde{\mathrm{F}}: \mathfrak{R}_{+}^{5} \rightarrow \mathfrak{R}$ so that for all $\mathrm{i}, \mathrm{i}=1, \ldots, \mathrm{n}$,

$$
F_{i}\left(Y_{1}, \ldots, Y_{n}, E_{1}, \ldots, E_{n}, Z_{1}, \ldots, Z_{n}\right)=\widetilde{F}\left(Y_{i}, Y, E_{i}, E, Z_{i}\right)
$$

Moreover, the existence of the function $\widetilde{F}\left(Y_{i}, Y, E_{i}, E, z_{i}\right)$ guarantees that net-income functions satisfy properties (A3) and (A4).

Since (A5) requires that a merger between two jurisdictions $i$ and $j$ should not affect any other jurisdiction,

$$
\begin{aligned}
& \widetilde{F}\left(Y_{i}, Y, E_{i}, E, z_{i}\right)+\widetilde{F}\left(Y_{j}, Y, E_{j}, E, z_{j}\right) \\
& =\widetilde{F}\left(Y_{i}+Y_{j}, Y, E_{i}+E_{j}, E, z_{i}+z_{j}\right)+\widetilde{F}(0, Y, 0, E, 0)
\end{aligned}
$$

is a necessary and sufficient condition. Referring to the empty-jurisdiction property (A1), the following Lemma can be stated immediately. 
Lemma 2: Net income functions $\mathrm{F}_{\mathrm{i}}: \mathfrak{R}_{+}^{3 \mathrm{n}} \rightarrow \mathfrak{R}, \mathrm{i}=1, \ldots, \mathrm{n}$ satisfy properties (A1), (A4), (A5) and (A6), if and only if $F_{i}\left(Y_{1}, \ldots, Y_{n}, E_{1}, \ldots, E_{n}, Z_{1}, \ldots, Z_{n}\right)=\widetilde{F}\left(Y_{i}, Y, E_{i}, E, Z_{i}\right), i=1, \ldots, n$, if $\widetilde{F}(0, Y, 0, E, 0)=0$ and if for all $i, j, i=1, \ldots, n, j=1, \ldots, n$,

$$
\widetilde{F}\left(Y_{i}, Y, E_{i}, E, z_{i}\right)+\widetilde{F}\left(Y_{j}, Y, E_{j}, E, z_{j}\right)=\widetilde{F}\left(Y_{i}+Y_{j}, Y, E_{i}+E_{j}, E, z_{i}+z_{j}\right) . \quad \#
$$

Hence, the net income function $\widetilde{F}$ is a generalised Cauchy function and a basic result from the theory on functional equations can be applied:

Lemma 3: Net income functions $\mathrm{F}_{\mathrm{i}}: \mathfrak{R}_{+}^{3 \mathrm{n}} \rightarrow \mathfrak{R}, \mathrm{i}=1, \ldots, \mathrm{n}$ satisfy properties (A1) till (A6), only if $F_{i}\left(Y_{1}, \ldots, Y_{n}, E_{1}, \ldots, E_{n}, Z_{1}, \ldots, Z_{n}\right)=\widetilde{F}\left(Y_{i}, Y, E_{i}, E, Z_{i}\right), i=1, \ldots, n$, and if there exist functions

$$
\begin{aligned}
& \mathrm{f}_{\mathrm{Y}}=\mathrm{f}_{\mathrm{Y}}(\mathrm{Y}, \mathrm{E}) \text {, where } \mathrm{f}_{\mathrm{Y}}: \mathfrak{R}_{+}^{2} \rightarrow \mathfrak{R}, \\
& \mathrm{f}_{\mathrm{E}}=\mathrm{f}_{\mathrm{E}}(\mathrm{Y}, \mathrm{E}) \text {, where } \mathrm{f}_{\mathrm{E}}: \mathfrak{R}_{+}^{2} \rightarrow \mathfrak{R},
\end{aligned}
$$

so that,

$$
\begin{aligned}
& \widetilde{F}\left(Y_{i}, Y, E_{i}, E, z_{i}\right) \\
& =f_{Y}(Y, E) Y_{i}-f_{E}(Y, E) E_{i}+\left[\left(1-f_{Y}(Y, E)\right) Y-\left(1-f_{E}(Y, E)\right) E\right] z_{i} .
\end{aligned}
$$

Proof: Using the previous lemma, taking into account that according to (A3) $\widetilde{\mathrm{F}}$ is bounded on the interval [-E, Y] and applying the basic theorem on generalised Cauchy equations [see Aczél (1966), p. 34 and p. 215 and Eichhorn (1978), p. 51], yields

$$
\widetilde{F}\left(Y_{i}, Y, E_{i}, E, z_{i}\right)=f_{Y}(Y, E) Y_{i}-f_{E}(Y, E) E_{i}+f_{z}(Y, E) z_{i}
$$

where $\mathrm{f}_{\mathrm{z}}: \mathfrak{R}_{+}^{2} \rightarrow \mathfrak{R}$. Using (A2),

$$
\begin{aligned}
& \sum_{i=1}^{n} \widetilde{F}\left(Y_{i}, Y, E_{i}, E, z_{i}\right)=\sum_{i=1}^{n}\left[f_{Y}(Y, E) Y_{i}-f_{E}(Y, E) E_{i}+f_{z}(Y, E) z_{i}\right]=Y-E \\
& \Rightarrow f_{z}(Y, E)=\left(1-f_{Y}(Y, E)\right) Y-\left(1-f_{E}(Y, E)\right) E
\end{aligned}
$$

QED. 


\section{Proof of theorem 2}

(a) Since $z_{i}$ and either $Y_{i}$ or $E_{i}$ can be set equal to zero, the monotonicity properties of $f_{Y}$ and $f_{E}$ can be obtained immediately from the inspection of $\widetilde{F}\left(Y_{i}, Y, E_{i}, E, z_{i}\right)$ $=f_{Y}(Y, E) Y_{i}-f_{E}(Y, E) E_{i}+\left[\left(1-f_{Y}(Y, E)\right) Y-\left(1-f_{E}(Y, E)\right) E\right] z_{i}$.

(b) For $\widetilde{F}\left(Y_{i}, Y, E_{i}, E, z_{i}\right)=f_{Y}(Y, E)\left(Y_{i}-Y z_{i}\right)-f_{E}(Y, E)\left(E_{i}-E z_{i}\right)+(Y-E) z_{i}, Y_{i}$ and $E_{i}$ are chosen such that $Y_{i}=Y_{i}$ and $E_{i}=E z_{i}$. If $Y_{j}$ for some $j \neq i$ is varied by $\Delta$, the change in $\widetilde{F}\left(Y_{i}, Y, E_{i}, E, z_{i}\right)$ is equal to $\left[1-f_{Y}(Y+\Delta, E)\right] z_{i} \Delta$. Hence from monotonicity with respect to income $Y_{j}$, with $j \neq i$, follows $f_{Y}(Y+\Delta, E) \leq 1$ and, therefore, $f_{Y}(Y, E) \leq 1$. If $Y_{i}$ is varied by $\Delta$ instead, the change in $\widetilde{F}\left(Y_{i}, Y, E_{i}, E, z_{i}\right)$ is equal to $\left[1-f_{Y}(Y+\Delta, E)\right] z_{i} \Delta+f_{Y}(Y+\Delta, E) \Delta$. Since $z_{i}$ might be arbitrarily close to zero, monotonicity with respect to income $\mathrm{Y}_{\mathrm{i}}$ demands $\mathrm{f}_{\mathrm{Y}}(\mathrm{Y}+\Delta, \mathrm{E}) \geq 0$ and thus $\mathrm{f}_{\mathrm{Y}}(\mathrm{Y}, \mathrm{E}) \geq 0$. Hence, (A7) ensures $0 \leq \mathrm{f}_{\mathrm{Y}}(\mathrm{Y}, \mathrm{E}) \leq 1$. Analogously (A8) requires $0 \leq \mathrm{f}_{\mathrm{E}}(\mathrm{Y}, \mathrm{E}) \leq 1$.

QED. 


\section{Monotonicity properties of (3)}

If $\mathrm{j} \neq \mathrm{i}$,

$$
\begin{aligned}
\frac{\partial F_{i}}{\partial Y_{j}} & =\frac{Y_{i}}{\pi\left(1+Y^{2}\right)}+\left(\pi-\arctan (Y)-\frac{Y}{1+Y^{2}}\right) \frac{z_{i}}{\pi} \\
& \geq \frac{Y_{i}}{\pi\left(1+Y^{2}\right)}+\left(\frac{\pi}{2}-\frac{Y}{1+Y^{2}}\right) \frac{Z_{i}}{\pi} \\
& \geq \frac{Y_{i}}{\pi\left(1+Y^{2}\right)} \geq 0, \\
\frac{\partial F_{i}}{\partial Y_{i}} & =\frac{\partial F_{i}}{\partial Y_{j}}+\frac{\arctan (Y)}{\pi} \geq \frac{\partial F_{i}}{\partial Y_{j}}, \\
\frac{\partial F_{i}}{\partial E_{j}} & =-\left[\frac{E_{i}}{\pi\left(1+E^{2}\right)}+\left(\pi-\arctan (E)-\frac{E}{1+E^{2}}\right) \frac{z_{i}}{\pi}\right] \\
& \leq-\left[\frac{E_{i}}{\pi\left(1+E^{2}\right)}+\left(\frac{\pi}{2}-\frac{E}{1+E^{2}}\right) \frac{z_{i}}{\pi}\right] \\
& \leq-\frac{E_{i}}{\pi\left(1+E^{2}\right)} \leq 0, \\
\frac{\partial F_{i}}{\partial Z_{i}} & =\frac{1}{\pi}\left[\left(\pi-\arctan _{i}(Y)\right) Y-(\pi-\arctan (E)) E\right] \frac{\partial z_{i}}{\partial Z_{i}} .
\end{aligned}
$$

The term in square brackets can be written as $\varphi(Y)$, where $\varphi(E)=0$. Since

$$
\frac{\partial \varphi}{\partial \mathrm{Y}}=\pi-\arctan (\mathrm{Y})-\frac{\mathrm{Y}}{1+\mathrm{Y}^{2}}>\frac{\pi}{2}-\frac{\mathrm{Y}}{1+\mathrm{Y}^{2}}>0
$$

$\partial \mathrm{F}_{\mathrm{i}} / \partial \mathrm{Z}_{\mathrm{i}}>0$ holds for $\mathrm{Y}>\mathrm{E}$. 


\section{References}

Aczél, J. (1966). Lectures on Functional Equations and their Applications. Academic Press. New York and London.

Aczél, J. and A. Pfingsten (1993). Constituent-Sensitive Public Fund Sharing. In: W.E. Diewert, K. Spremann, F. Stehling (Eds.). Mathematical Modelling in Economics. Springer-Verlag. Berlin, Heidelberg, New York. 3 - 10.

Baltagi, B.H. (1995). Econometric Analysis of Panel Data. John Wiley. Chichester, New York.

Bowles, R. and P. Jones (1992), Equity and the EC Budget: A Pooled Cross-Section Time Series Analysis. Journal of European Social Policy 2. 87 - 106.

Buhl, H.U. and A. Pfingsten (1986). Eigenschaften und Verfahren für einen angemessenen Länderfinanzausgleich in der Bundesrepublik Deutschland. Finanzarchiv N.F. $44.98-109$.

Buhl, H.U. and A. Pfingsten (1990). On the Distribution of Public Funds. European Journal of Political Economy 6. $363-376$.

Buhl, H.U. and A. Pfingsten (1991). Zehn Gebote für Finanzausgleichsverfahren und ihre Implikationen. Wirtschaftsdienst 1991/IX. 481 - 484.

Deutsche Bundesbank (1999). Monatsbericht 51(7). Frankfurt: Deutsche Bundesbank.

Eichhorn, W. (1978). Functional Equations in Economics. Addison-Wesley. Reading, Massachusetts.

Hausman, J.A. (1978). Specification Tests in Econometrics. Econometrica 46. 1251 1271. 
Molle, W. (1997). The Economics of European Integration, Ashgate. Aldershot.

Moulin, H. (1987). Equal or Proportional Division of a Surplus, and Other Methods. International Journal of Game Theory 16. 161 - 186.

Moulton, B.R. (1990). An Illustration of a Pitfall in Estimating the Effects of Aggregate Variables on Micro Units. Review of Economics and Statistics 72. 334 - 338.

White, H. (1980). A Heteroscedasticity-Consistent Covariance Matrix Estimator and a Direct Test for Heteroscedasticity. Econometrica 48. $817-838$.

Wissenschaftlicher Beirat beim Bundesministerium für Wirtschaft und Technologie (1999). Neuordnung des Finanzierungssystems der Europäischen Gemeinschaft. Gutachten. BMWi-Dokumentation 455.

Young, H.P. (1988). Distributive Justice in Taxation. Journal of Economic Theory 44. $321-335$. 


\section{CESifo Working Paper Series}

(for full list see www.cesifo.de)

781 Clemens Fuest and Alfons Weichenrieder, Tax Competition and Profit Shifting: On the Relationship between Personal and Corporate Tax Rates, October 2002

782 Jan Bouckaert and Hans Degryse, Softening Competition by Enhancing Entry: An Example from the Banking Industry, October 2002

783 Johann K. Brunner and Susanne Pech, Adverse Selection in the Annuity Market with Sequential and Simultaneous Insurance Demand, October 2002

784 Gregory D. Hess and Eduard Pelz, The Economic Welfare Cost of Conflict: An Empirical Assessment, October 2002

785 Jan Erik Askildsen, Uwe Jirjahn, and Stephen C. Smith, Works Councils and Environmental Investment: Theory and Evidence from German Panel Data, October 2002

786 Geir H. Bjønnes, Dagfinn Rime, and Haakon O. Aa. Solheim, Volume and Volatility in the FX-Market: Does it matter who you are?, October 2002

787 John Evans and John Fingleton, Entry Regulation and the Influence of an Incumbent Special Interest Group, October 2002

788 Wolfgang Ochel, International Comparisons and Transfer of Labour Market Institutions, October 2002

789 B. Gabriela Mundaca, Moral Hazard Effects of Bailing out under Asymmetric Information, October 2002

790 Gene M. Grossman and Edwin L.-C. Lai, International Protection of Intellectual Property, October 2002

791 John Hassler, José V. Rodriguez Mora, Kjetil Storesletten, and Fabrizio Zilibotti, A Positive Theory of Geographic Mobility and Social Insurance, October 2002

792 Paul De Grauwe and Marianna Grimaldi, The Exchange Rate in a Model with Heterogeneous Agents and Transactions Costs, October 2002

793 Guido Friebel and Mariassunta Giannetti, Fighting for Talent: Risk-shifting, Corporate Volatility, and Organizational Change, October 2002

794 Jan Erik Askildsen, Badi H. Baltagi, and Tor Helge Holmås, Will Increased Wages Reduce Shortage of Nurses? A Panel Data Analysis of Nurses' Labour Supply, October 2002 
795 Marko Köthenbürger and Panu Poutvaara, Social Security Reform and Intergenerational Trade: Is there Scope for a Pareto-Improvement?, October 2002

796 Paul De Grauwe and Laura Rinaldi, A Model of the Card Payment System and the Interchange Fee, October 2002

797 Volker Böhm and Tomoo Kikuchi, Dynamics of Endogenous Business Cycles and Exchange Rate Volatility, October 2002

798 Mariam Camarero, Javier Ordóñez, and Cecilio Tamarit, The Euro-Dollar Exchange Rate: Is it Fundamental?, October 2002

799 Misa Tanaka, How Do Bank Capital and Capital Adequacy Regulation Affect the Monetary Transmission Mechanism?, October 2002

800 Jörg Baten and Andrea Wagner, Autarchy, Market Disintegration, and Health: The Mortality and Nutritional Crisis in Nazi Germany, 1933-1937, October 2002

801 Saku Aura, Uncommitted Couples: Some Efficiency and Policy Implications of Marital Bargaining, October 2002

802 Wolfram F. Richter, Delaying Integration of Immigrant Labor for the Purpose of Taxation, October 2002

803 Gil S. Epstein and Shmuel Nitzan, The Politics of Randomness, October 2002

804 John Hassler and José V. Rodriguez Mora, Should UI Benefits Really Fall over Time?, October 2002

805 Friedrich Breyer and Stefan Felder, The Dead-anyway Effect Revis(it)ed, October 2002

806 Assar Lindbeck and Solveig Wikström, E-exchange and the Boundary between Households and Organizations, November 2002

807 Dieter Bös, Contests Among Bureaucrats, November 2002

808 Steven Brakman, Harry Garretsen, and Marc Schramm, The Strategic Bombing of German Cities during World War II and its Impact on City Growth, November 2002

809 Florian Englmaier and Achim Wambach, Contracts and Inequity Aversion, November 2002

810 Sarbajit Sengupta, Delegating Recruitment under Asymmetric Information, December 2002

811 Rajshri Jayaraman, On the Partial Public Provision of a Private Good, December 2002

812 Stéphanie Stolz, Banking Supervision in Integrated Financial Markets: Implications for the EU, December 2002 
813 Christian Keuschnigg, Taxation of a Venture Capitalist with a Portfolio of Firms, December 2002

814 Inés Macho-Stadler and David Pérez-Castrillo, Settlement in Tax Evasion Prosecution, December 2002

815 Rainer Niemann and Dirk Simons, Costs, Benefits, and Tax-induced Distortions of Stock Option Plans, December 2002

816 Jan-Egbert Sturm and Barry Williams, Deregulation, Entry of Foreign Banks and Bank Efficiency in Australia, December 2002

817 V. Anton Muscatelli, Patrizio Tirelli, and Carmine Trecroci, Monetary and Fiscal Policy Interactions over the Cycle: Some Empirical Evidence, December 2002

818 Claude Hillinger, A General Theory of Price and Quantity Aggregation and Welfare Measurement, December 2002

819 Erkki Koskela and Ronnie Schöb, Optimal Capital Taxation in Economies with Unionised and Competitive Labour Markets, December 2002

820 Sheilagh Ogilvie, Guilds, Efficiency, and Social Capital: Evidence from German ProtoIndustry, December 2002

821 Hans Gersbach and Verena Liessem, Financing Democracy, December 2002

822 Costas Hadjiyiannis, Panos Hatzipanayotou, and Michael S. Michael, Optimal Tax Policies with Private-Public Clean-Up, Cross-Border Pollution and Capital Mobility, December 2002

823 François Ortalo-Magné and Sven Rady, Homeownership: Low Household Mobility, Volatile Housing Prices, High Income Dispersion, December 2002

824 Syed M. Ahsan and Panagiotis Tsigaris, Measuring the Social Discount Rate under Uncertainty: A Methodology and Application, December 2002

825 Kai A. Konrad, Altruism and Envy in Contests: An Evolutionarily Stable Symbiosis, December 2002

826 Robert S. Chirinko and Huntley Schaller, A Revealed Preference Approach to Understanding Corporate Governance Problems: Evidence from Canada, December 2002

827 Geir B. Asheim, Green National Accounting for Welfare and Sustainability: A Taxonomy of Assumptions and Results, December 2002

828 Andrea Gebauer, Chang Woon Nam, and Rüdiger Parsche, Lessons of the 1999 Abolition of Intra-EU Duty Free Sales for Eastern European EU Candidates, December 2002

829 Giacomo Corneo, Work and Television, December 2002 
830 Vivek H. Dehejia and Yiagadeesen Samy, Trade and Labour Standards - Theory, New Empirical Evidence, and Policy Implications, December 2002

831 Geir B. Asheim and Wolfgang Buchholz, A General Approach to Welfare Measurement through National Income Accounting, December 2002

832 Aaron Tornell and Frank Westermann, The Credit Channel in Middle Income Countries, January 2003

833 Gebhard Flaig, Time Series Properties of the German Monthly Production Index, January 2003

834 Campbell Leith and Jim Malley, Estimated Open Economy New Keynesian Phillips Curves for the G7, January 2003

835 Burkhard Heer and Bernd Süssmuth, Inflation and Wealth Distribution, January 2003

836 Erkki Koskela and Leopold von Thadden, Optimal Factor Taxation under Wage Bargaining - A Dynamic Perspective, January 2003

837 Carola Grün and Stephan Klasen, Growth, Income Distribution, and Well-Being: Comparisons across Space and Time, January 2003

838 Robert S. Chirinko and Ulf von Kalckreuth, On the German Monetary Transmission Mechanism: Interest Rate and Credit Channels for Investment Spending, January 2003

839 Sascha O. Becker, Andrea Ichino, and Giovanni Peri, How Large is the "Brain Drain" from Italy?", January 2003

840 Albert Berry and John Serieux, All About the Giants: Probing the Influences on Growth and Income Inequality at the End of the $20^{\text {th }}$ Century, January 2003

841 Robert Fenge and Martin Werding, Ageing and the Tax Implied in Public Pension Schemes: Simulations for Selected OECD Countries, January 2003

842 Robert Fenge and Martin Werding, Ageing and Fiscal Imbalances Across Generations: Concepts of Measurement, January 2003

843 Giovanni Andrea Cornia, The Impact of Liberalisation and Globalisation on Income Inequality in Developing and Transitional Economies, January 2003

844 Peter Fredriksson and Per Johansson, Program Evaluation and Random Program Starts, January 2003

845 Bernd Hayo and Matthias Wrede, Fiscal Equalisation: Principles and an Application to the European Union, January 2003 